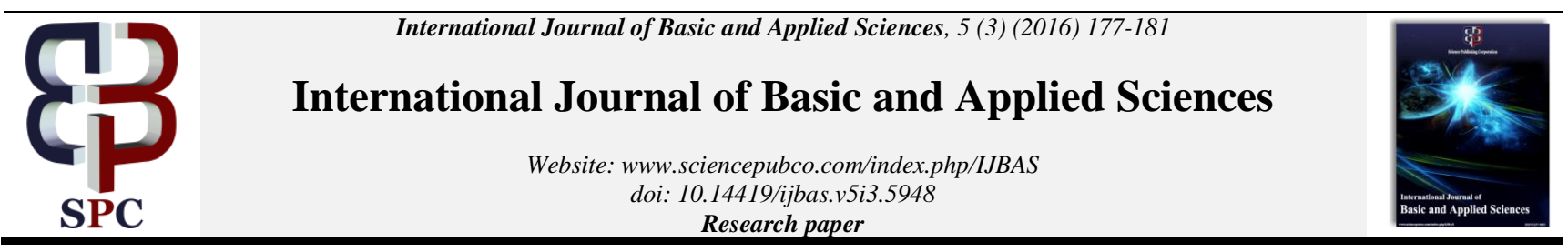

\title{
Relationship between Selected Factors of Motivation, Employee Engagement and Employee Performance Among Nurses at Adventist hospital
}

\author{
Rolyana Ferinia $^{1 *}$, Tjutju Yuniarsi ${ }^{2}$, H. Disman ${ }^{3}$ \\ ${ }^{1}$ Research Scholar, Universitas Pendidikan Indonesia, Department of Business Universitas Advent Indonesia, Bandung, Kolonel Masturi \\ Street, \#288, Parongpong, Bandung, West Java, Indonesia \\ ${ }^{2}$ Professor Department of Management, Universitas Pendidikan Indonesia. Dr. Setiabudhi Street, \#229. Bandung 40154, \\ West Java, Indonesia \\ ${ }^{3}$ Professor Department of Economic Education, Universitas Pendidikan Indonesia. Dr. Setiabudhi Street, \#229. Bandung 40154, \\ West Java, Indonesia \\ *Corresponding author E-mail: sibuearolyana@gmail.com
}

\begin{abstract}
This study examined the relationship between selected factors of motivation, employee engagement and employee performance among nurses at Adventist Hospital. The quantitative research method of collecting data was used. The questionnaire was distributed nurses at Adventist Hospitals using cluster sampling. And Taro Yamane formula. A sample of 435 nurses was selected to fill the questionnaire. The findings showed that [1] the need for achievement significantly and positively influenced by satisfaction $(\beta=0$. 29), [2] need for achievement significantly and positively influenced by performance $(\beta=0.15)$, [3] satisfaction significantly and positively influenced by advocacy $(\beta=0.84)$ and $[4]$ advocacy significantly and positively influenced by performance $(\beta=0.60)$.
\end{abstract}

Keywords: Need of Achievement; Satisfaction; Advocacy; Performance.

\section{Introduction}

One of the essential need in hospitals is having motivated and engaged work force individuals. Employees who are motivated to work will engage and give a good performance [1] "every manager must ensure that the employees are highly motivated. Employees with high motivation will have a high sense of belonging to the organization, increasing in quality of work, increasing productivity and increasing employee performance". Engaged employees causes an increase of performance. Employees with high engagement have 1.3 times higher performance than employees who are not engaged, and have five times higher probability to remain in the organization [2].

In reality, based on some research conducted by several researchers showed that the performance of nurses in hospital services does not match expectations. It can be seen from the number of complaints from users of the hospital services. Among the complaints are about convulated registration procedure outpatient / inpatient, uncertainty of problem solving such as to decide which doctor more compotent to patient illness and attitude of nurses who are less responsive to patient demand. One of the complaints of patients to nurses that the nurses are less responsive to the needs of the patient and nurses weren't available when needed or didn't respond quickly to requests for help [3]. According to the article, nurses in the health care have low performance. Low performance can be caused by many factors. In this study, the factors that affect performance will be examined with motivation and employee engagement. [1], [4], [5], [6], [7].

\section{Performance}

Performance is what "is done" or "not done" by the employees. Performance as the contribution of each individual to the organizations who employ them. "Performance means both behavior and results. Behaviors come up from the person and change performance from something abstract to a process of action. Not just the instruments for results, behaviors also means the outcomes with mentally and physically venture that can be applied in the workplace, and may be assessed separately from the outcome.The performance will always be associated with the working standards. Working standards related to the dimensions which serve as the basis made by the organization to measure performance" [8]. In this study dimension of Performance will be used are [10]:

1) "Quality: The degree to which the process or result of carrying out an activity approaches perfection, in terms of either conforming to some ideal way of performing the activity or fulfilling the activity's intended purpose.

2) Quantity: the amount produced, expressed in such terms as a dollar value, a number of units or number of completed activity cycles.

3) Timeliness: The degree to which an activity is completed, or a result produced, at the earliest time desirable from the standpoints of both coordinating with the outputs of others and maximizing the time available for other activities.

4) Cost-effectiveness: The degree to which the use of the organization's resources (e.g. human, monetary, technological, material) is maximized in the sense of getting the highest 
gain or reduction in loss from each unit or instance of the use of a resource.

5) The need of supervision: The degree to which a performer can carry out a job function without either having to request supervisory assistance or requiring supervisory intervention to prevent an adverse outcome.

6) Interpersonal impact: The degree to which a performer promotes feelings of self-esteem, goodwill, and cooperation among co-workers and subordinates."

\section{Motivation}

Motivation is the power that comes from within and outside oneself to increase the spirit and endurance to accomplish something to be desired [11] and confirmed by Certo, motivation is an inner state of an individual that causes him or her to act in a manner that ensures some of the objectives are achieved [12]. Greenberg defined motivation as a set of processes that arouses, control and nurture human conduct toward reaching some goals. Passion conjunction with the drive or the energy behind our actions, means directly toward their behavior and keep taking behavior is how long people will persist in trying to meet their goals [4]. There are many theories of motivation raised, but in this study, the theory of motivation that will be used is McClelland motivation theory: the need for achievement, need for affiliation and the need for Power [13], [14].

\section{Employee engagement}

Engagement is similar to, but not identical with motivation. Marciano explains that engagement refers to the notion of intrinsic deep-rooted, and sweeping commitment, pride, and loyalty which cannot be easily altered [7]. In contrast, the level of motivation is strongly influenced by external factors, notably expectations, efforts or achievements to be rewarded appreciated. Therefore, Marciano provide a definition of engagement as everything related to commitment [7]; In this study the model that will be used are satisfaction, commitments and Advocacy, [2]

After reviewing theoretical review, a conceptual model was developed (Fig.1). The literature indicates that motivation is one of the great important behavior in organizations. In this study, we expand this literature by recognizing one from three dimensions of McClelland motivation that is the need for achievement has relationship toward performance. As well as shown in the literature, selected engagement dimension includes satisfaction and advocacy are positively related to employee performance. In this study, employee engagement mediated the relationship between the need for achievement with employee performance. Thus, the intent of this study is to explore the relationship between selected factors of a need for achievement, satisfaction, advocacy and performance. As a result, this study attempted to find out the answer for the following question:

1) What is the relationship between need for achievement and employee satisfaction?

2) What is the relationship between need for achievement and employee performance?

3) What is the relationship between employee satisfaction and employee advocacy?

4) What is the relationship between employee advocacy and performance?

\section{Related research}

In connection with this research, there are several related studies that strengthen the relationship between each of the variables that will be described below:
1) Tyilana conducted research about motivation, namely achievement and its relation with satisfaction. The result showed that three motivating factors achievement, recognition and work itself cause $88 \%$ job satisfaction [15].

2) Astuti conducted research and found that achievement motivation and affiliated motivation are significantly influenced to employee satisfaction [16]

3) Sutjitra conducted research with 100 employees and the result of the research is there is a significant impact of employee job satisfaction towards employee job performance.[17]

4) Koesmono conducted research with 215 employees with three independent variables; organizational culture, servant leadership and job satisfaction and two dependent variables organizational commitment a job performance. The result of the research showed that organizational culture, servant leadership and job satisfaction have a positive effect to organizational commitment and job performance [18]

5) Contributions need for achievement and performance more in the sales and marketing area. According to the research conducted by Uduju, a high need for achievement, affiliation and power in salespeople will enforce at a high-level contribution of performance [19] Robert Eisenberger explained that achievement-oriented employees were associated with greater positive mood, task interest and performance[20]. Collins et.al found that need of achievement of an entrepreneur was correlated with career and performance. Among achievement-oriented employees only, high skill and challenge were associated with greater positive mood, task interest, and performance than other skill/challenge combinations [21]

6) Susanta conducted research about the effect of relationship quality on customer advocacy among bank employees and found that there is a direct effect of satisfaction and commitment toward advocacy [22].

\section{Objectives of the study and research hy- potheses}

This study was conducted to determine the relationship between selected factors motivation, employee engagement and performance as mention below:

1) Determine the relationship between need for achievement and employee satisfaction.

2) Determine the relationship between need for achievement and employee performance.

3) Determine the relationship between employee satisfaction and employee advocacy.

4) Determine the relationship between employee advocacy and performance.

The following hypotheses were formulated for this study:

1) H1: There is a significant relationship between need for achievement and employee satisfaction.

2) $\mathrm{H} 2$ : There is a significant relationship between need for achievement and employee performance.

3) H3: There is a significant relationship between employee satisfaction and employee advocacy.

4) H4: There is a significant relationship between employee advocacy and performance.

Therefore, the research conceptual model in this study is: 


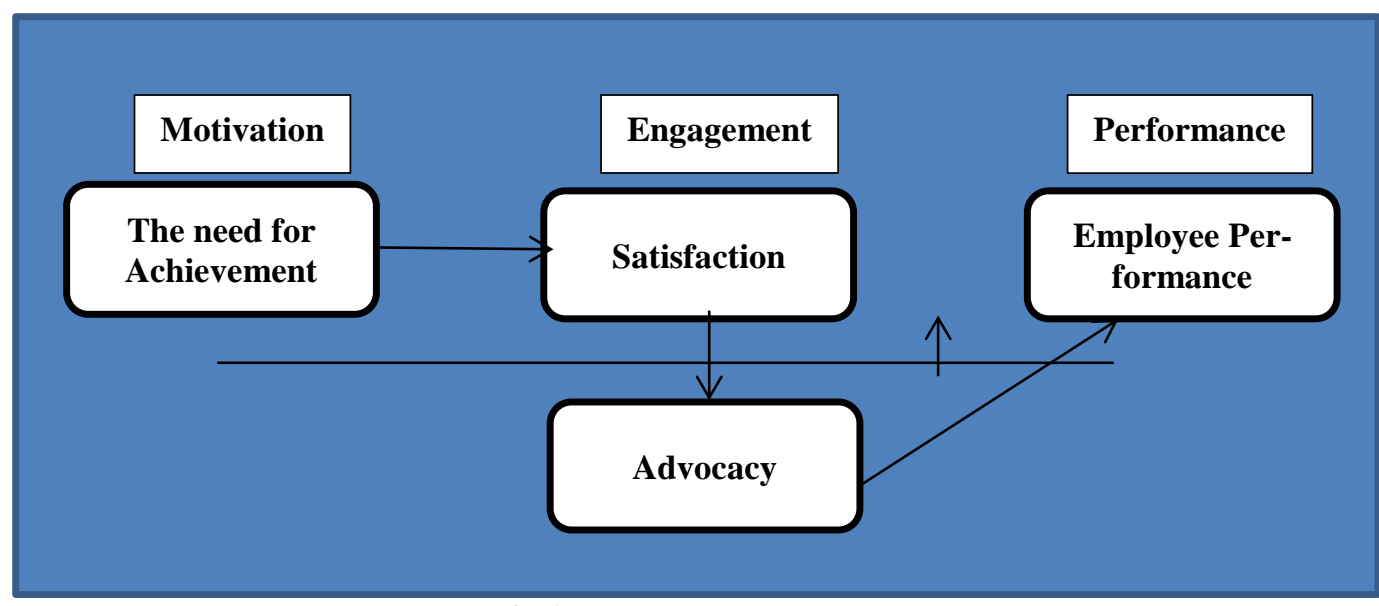

Fig. 1: Research Conceptual Model.

\section{Method}

\subsection{Research design}

There are many types of research methodology. One of the basic types of research methodology is quantitative research. According to Kothari, "quantitative research is based on the measurement of quantity or amount, it is applicable to phenomena that can be expressed in terms of quantity. The major approach in this study was using quantitative research [23].

\subsection{Participants}

The study was conducted in the nonprofit organization (Adventist hospital) that located in the different island of Indonesia, namely Medan Adventist hospital located in Sumatera, Bandar Lampung Adventist Hospital located in Sumatera, Bandung Adventist Hospital, located in Java and Manado Adventist Hospital, located in Sulawesi. Sampling was done by a proportional random sampling technique The questionnaires were administered to 435 nurses from four different hospitals, Likert scale form were used in the questionnaires with closed questions.

\subsection{Instruments}

Data collection techniques used is this study was structured questionnaires. Structured questionnaires are those questionnaires in which there are definite, concrete and pre-determined questions. The questions are presented with exactly the same wording and in the same order to all respondents. Resort is taken to this sort of standardization to ensure that all respondents reply to the same set of questions [23]. Respondents answer questions on a 5 point Likert Singh [24].

The theory used to measure the selected dimensions of Mc Clelland motivation taken from Robbins \& Coulter [13] and Moorhead \& Griffin [14]; need for achievement of 4 items. The theory used to measure selected dimensions of employee engagement taken from Schiemann [2]; satisfaction 4 items and advocacy 3 items. Originally, the performance theory was used to measure six dimensions of performance is taken from Bernardin \& Russel. [10] quality of work 2 items, quantity of work 2 items, timeless 2 items, cost-effectiveness 2 items, need of supervision 2 items and interpersonal impact 2 items.

\subsection{Validity and reliability}

Pearson Product Moment was used to determine the validity of all items with the standard correlation value above 0.30 . Cronbach's alpha test was used to determine the reliability, the cronbach alpha coefficient values should be above 0.60 [24]. The findings all datas are valid and reliable.

\section{Analysis method}

Structural equation modelling (SEM) is used for investigating relationship between the need for achievement, satisfaction, advocacy and employee performance. SEM uses various types of models to depict relationships among observed variables, with the same basic goal of providing a quantitative test of a theoretical model hypothesized indirect and direct relationships between variables by the researcher [25]. The structural Equation Modelling using AMOS software.

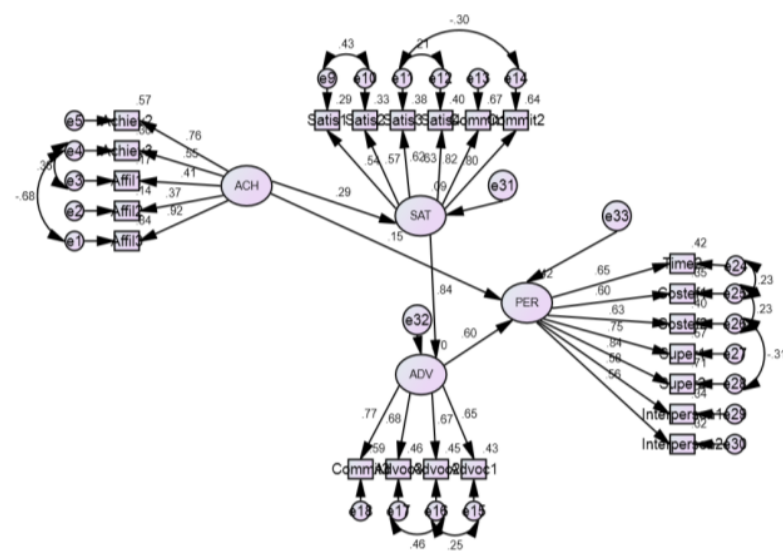

Fig. 1: Result of Structural Equation Modelling of Motivation, Engagement toward Performance.

Confirmatory factor analysis (CFA) was performed to confirm the validity of the constructs. We used most common indices to evaluate the confirmatory factor analysis models, the result of CFA is written below.

Table 1: Model Fit Summary of Structural Equation Modelling of Motivation, Engagement toward Performance

\begin{tabular}{ll}
\hline CFA Parameter & Result \\
\hline Chi-square & 386.307 \\
GFI & 0.919 \\
RMSEA & 0.05 \\
AGFI & 0.985 \\
CFI & 0.794 \\
PNFI & 0.563 \\
\hline
\end{tabular}

\section{Findings}

The results from Table 1 indicate about loading factors scores of need for achievement, satisfaction, advocacy and performance. Loading factors of need for achievement are 0.76, 0.55, 0.41, 0.37 and 0.92 . These loading factors are significant $(\mathrm{p}=0.00)$. Loading factors of satisfaction are $0.80,0.82,0.62,0.57$ and 0.54 , with a 
level of significance were $\mathrm{p}=0.00$. Loading factors of advocacy are $0.77,0.68,0.67$ and 0.65 with a level of significance were $\mathrm{p}=0.00$. Loading factor of performance are $0.63,0.56,0.58,0.84,0,75$, $0.63,0.60$ and 0.65 with level of significance were $p=0.00$

Moreover, the hypothesis testing proved that [1] the need for achievement significantly and positively influenced by satisfaction $(\beta=0.29),[2]$ need for achievement significantly and positively influenced by performance $(\beta=0.15)$, [3] satisfaction significantly and positively influenced by advocacy $(\beta=0.84)$ and $[4]$ advocacy significantly and positively influenced by performance $(\beta=0.60)$

\section{Discussion and conclusion}

Need of achievement, satisfaction and advocacy showed to affect performance. This study has revealed that satisfaction toward advocacy had the highest correlation with $\beta=0.84$. It can be explain that satisfaction is able to give value to the increasing of advocacy. According to empirical data, there are some reason which can be explained. First, hospital administrators provided a policy to give permission and easiness to every nurse to take a higher level of education both academic level of education and professional level of education at Adventist University of Indonesia, Bandung. The policy causing an employee sense of belonging to the company and the sense has evolved into a relationship and a desire to give extra work effort beyond company standards. Second, Every year, Adventist hospitals also have an annual gettogether program where administrators will specify the place of recreation, organize events and give some recreation money. At a designated place, they will get to know co-workers, close to the leaders and share experiences with one another. Social interaction that occurs during the annual get-together program lead to an engagement among employees and then raises a desire to meet and then collaborate in the workplace beyond the time required without asking for extra payment. Third, every nurse should joined morning worship and devotional before they start their activities on the day to motivated and strengthened them to face the day. These activities carried out regularly and make employees feel connected to God. The outcomes nurses feel they are satisfied with their workplace, they come to work before the time to prepare themselves for attending devotion, they enjoy themselves, and they willing to work the extra mile.

Another important thing from the finding is about three independent variables, namely the need of achievement, satisfaction and advocacy, advocacy had a high correlation to dependent variable performance $(\beta=0.60)$, means advocacy played an important role in Adventist Hospitals. This finding supported by Albrecht stated that "when employees are engaged, a range of behavior and cognitive and affective states are more likely to occur, such as effort, extra-role behavior, and advocacy [26]. Corroborated by the results of research that have been done in Indonesia to female employees that is employee involvement and significant positive effect on employee job satisfaction of women [27].

This study also proved that the need of achievement toward performance had lowest loading factor $(\beta=0.15)$. The need of achievement had a weak contribution to explain performance. It was observed that payroll system that applies in the Adventist Hospital is one of the factors why the need of achievement has a weak correlation with performance. First, Payroll systems that run at Adventist hospital is "point" payroll system with 100 points for top point salary. An employee with 10 years working experience will reach a top point salary. After employees reach 100 points, then there are two possibilities that occur in the performance of the employee that he or she will continue to work optimally, or she or he would not work with a maximum of even worse performance because they think their salaries have to be positioned top point.

\section{Implication of the research}

The implications of the research suggest that administrators should nurture and cultivate satisfaction and build a strong advocacy among employees in the workplace to boost employee performance because employees really need to work for the material and psychological satisfaction they can achieve, and that their work is therefore an instrument used towards their own ends [28].

\section{Limitations and future research}

This research paper has several limitations. First, A sample was taken from four hospitals in different islands of Indonesia with different culture, all of these influence the way of employee answer the questionnaire about motivation, employee engagement and performance. Each culture has a different point of view in answering the statement and could lead to misunderstanding for another region therefore it is best to examine each hospital rather than combined. Second, Not all theories of motivation, employee engagement applicable to nurses at Adventist Hospital it can be caused by various factors such as organizational culture, work ethics, and employee attitude, therefore, further research is needed. Thrid, the respondents did not answer the questionnaire intently thus, the answer may not be on target. Fourth, this research was conducted only to nurses. Further research should be taken for office employees, manufacture employees and other human resources area.

\section{Significance of the study}

This study contributes to knowledge as well as the literature, this was because the research results will devote the empirical data for literature review and helped to define and enhance the importance of need for achievement as a motivation driver so employee will be satisfied and advocated with the organization and will give high level of performance to the organization.

This study also important for Adventist Hospital foundation and management to realize with a need for achievement of every individual in enhancing satisfaction, advocacy and employee performance. Therefore, Adventist Hospital foundation and leaders can use this study as keys to determine the factors of achievement that should be rewarded to employees in order to enhance and rectify their satisfaction, advocacy and job performance at their workplace.

These study findings are important for managers and human resource management department to recognize and manage the important point of need for achievement, employee satisfaction and employee advocacy that will engage employees' performance at the workplace. When the employees need for achievement, satisfaction and advocacy fulfilled, they will perform the highest level of performance.

\section{Future research}

Research that has been done covers the total respondents Adventist hospital. Therefore, for future research, this study needs to be replicated in each Adventist Hospital to investigate which strongest drivers of motivation and engagement that affect direct and indirect to the performance.

\section{References}

[1] Kondalkar, V.G. (2007). Organizational Behaviour. New Delhi: New Age International.

[2] Schiemann, William, A. (2011). Alignment, Capability, Engagement. Jakarta:PPM.

[3] Wong, Michelle. (2012). 3 Big Problems Facing Nursing Today. Artikel [Internet]. 
[4] Diunduh: http://www.healthecareers.com/article/3-big-problemsfacing-nursing today/170629. Di akses 23 Desember 2014. [4] Greenberg, Jerald. (2011). Behavior in Organizations. 10th ed. England: Pearson.

[5] Robbins, Stephen. P. (2006). Organizational Behaviour. New Jersey: Prentice Hall.

[6] Hall-Lengnick, Mark, L \& Hall-Lengnick, Cynthia, A. (2003). Human Resource Management in th Knowledge Economy. San Francisco: Berret-Koehler Publishers.

[7] Marciano, Paul. L. (2010). Carrots and Sticks Don't Work. NY: McGrow \& Hill.

[8] Stewart, Greg L. \& Brown, Kenneth G. (2011). Human Resources Management, $2^{\text {nd }}$ Edition. USA: John Wiley and Sons, Inc.

[9] Brumbach, G. B. (1998). Some Ideas, Issues, and Predictions abou Performance Management, Public Personnel Management. Winter, pages $387-402$.

[10] Bernardin. H.J \& Russel J.E.A. (2013). Human Resources Manajement. Singapore: Nc GrawHill. Inc

[11] Danny, Samson \& Daft, Richard L. (2015). Fundamentals of Management. 5th Edition. NZ: Cengage Learning.

[12] Certo, Samuel C. (1985). Management of Organizations and $\mathrm{Hu}$ man Resources. Iowa: Wm.C. Brown Publishers.

[13] Robbins, Stephen. P \& Coulter, Mary. (2007). Manajemen. Alih Bahasa Harry Slamet \& Ernawati Lestari. Jakarta: Indeks.

[14] Moorhead, Gregory \& Griffin, Ricky W. (2013). Perilaku Organisasi. Edisi 9. Jakarta. Salemba Empat.

[15] Tyilana, Xolani Enoch. (2005). The Impact of Motivation on Job Satisfaction Amongst

[16] Employees of a National Broadcaster. Short Dissertation. Faculty of Management University of Johannesburg.

[17] Astuti, Hera Dzaki, Iskandar, Dadang. (2015). Pengaruh Motivasi Terhadap Kepuasan Kerja Karyawan. Skripsi. Manajemen BIsnis Telekomunikasi dan Informasi, Fakultas Ekonomi Bisnis. Uniersitas Telkom Bandung. [17] Sutjitra, Deilan. (2015). the Impact of Employee Job Satisfaction towards Employee Job Performance at Pry. Ibuss Management. Volume 3, no 3 pg. 325-336.

[18] Koesmono, H. Teman. (2014). The Influence of Organizationa Culture, Servant Leadership and Job Satisfaction Toward Organizational Commitment and Job Performance Through Work Motivation as Moderating Variables for Lecturer in Economic andbManajemen of Private Universities. Educational Research International, Volume 3. Pg. 25-39.

[19] Uduju, Joseph I, Ankeli, Marjorie, O. (2013). Need For Achievement, Affiliation, and Power the Possible Sales Manager's Actions for Exceptional Sales force Performance. Research Journal of Finance and Accounting. Vol 4 no 9, page 96-103.

[20] Eisenberger, Robert, Jones, Janson R, Stinglhanber, Florence Shanock, Linda and Randall, Amanda T. (2005). Flow Experiences at work: for high need achievers alone? Journal of Organization Behavior. Vol. 26. Page 755-775. http://dx.doi.org/10.1002/job.337.

[21] Collins, Christopher, Hanges, Paul, J and Locke, Edwin. A. (2004) The Relationship of Achievement Motivation to Entrepreneurial Behavior. A Meta-Analysis. Article, Cornell University ILR School.

[22] Susanta, Alhabsji, Taher, Idrus M.S, Nimran, Umar. (2013). the Effect of Relationship Quality on Customer Advocacy: The Mediating Role of Loyalty. OSR Journal of Business and Management. Vol. 10, no 4. Pg. 41-52. http://dx.doi.org/10.9790/487x-1044152.

[23] Kothari, C.R. (2004). Research Methodology. New Delhi: New Age International Limited.

[24] Singh, Yoqesh Kumar. (2006). Fundamental of Research Methodology \& Statistics. New Delhi: New Age International (P) Limited

[25] Schermerhorn. Dkk. (2010). Organizational Behaviour. $1 \mathrm{~g} 1^{\text {th }}$ edition. USA: John Wiley \& Sons. Inc.

[26] Albrecht. Simon L. (2010). Hand book of Employee Engagement. USA: Edward ElgarPublishing Limited. http://dx.doi.org/10.4337/9781849806374.

[27] Dharmayanti, Ratna. (2006). Pengaruh Konflik Keluarga, Keterlibatan Pekerjaan \& Tekanan Pekerjaan terhadap Kepuasan KErja Karyawan Wanita Studi pada Nusantara Tour \&Trael Kantor Cabang dan Kantor Pusat Semarang. Jurnal Studi Manajemen dan Organisasi. Vol 3. No 2. Pg. 93.

[28] Tyson, Shaun. (2006). Essentials of Human Resources Management. USA: Elsevier. 